\title{
A01木質ペレットストーブを用いたスターリングエンジン発電の可能性
}

\section{The Possibility of Electric Generation by Stirling Engine Using Wood Pellet Stoves}

\author{
准 丹澤 篤（エノモト） 正 濱口和洋（明星大） 正 関谷弘志（産総研） \\ Atsushi TANZAWA, ENOMOTO CO., LTD, Uenohara, Yamanashi \\ Kazuhiro HAMAGUCHI, Meisei University, Hino, Tokyo \\ Hiroshi SEKIYA, AIST, Tsukuba, Ibaraki
}

\begin{abstract}
The forest area of Japan is almost equal to that of Sweden. However, the utilization of the wood biomass in Japan has not been advancing. By the soaring oil prices from last year, the wood pellet price has become almost equivalent to the kerosene price at the standard heat quantity. As a result, if the supply system of the wood pellet becomes systematic, the wood pellet stoves and boilers would be more widely used. In this study, effective utilization of waste heat in the pellet stove is noticed. The system generating the electric power from not only conventional space heating by the stove but also the waste heat is constructed. And, the possibility of generating the electric power has been investigated experimentally. The waste heat of the stove is utilized for driving of the Stirling engine generator and the hot water supply. The possibility of electric power generation using a wood pellet stove is verified.
\end{abstract}

Key Words : Biomass, Wood pellet, Stove, Stirling engine, Electric generation

\section{1. 緒 言}

1997 年 12 月京都において開催された COP3(気候変動枠 組条約第 3 回締約国会議)により、日本における温室効果ガ ス排出量が 1990 年を基準年として 2008 年から 2012 年の 間に $6 \%$ 削減するよう求められている。この数值目標の達 成には、化石燃料の使用抑制並びに使用機器の効率向上と ともに再生可能エネルギの積極的な活用が必要不可欠であ る。化石燃料を使用する機器の効率向上策には、エネルギ 機器そのものの効率向上が第一であるが、コージェネレー ションシステムの導入も挙げられる。昨今、一般家庭に都 市ガスを燃料としたガスエンジン利用の $1 \mathrm{~kW}$ 級コージェ ネレーションシステムが販売されるとともに、燃料電池 (PEFC)を利用したコージェネレーションシステムの試験 的な販売も開始された。一方、再生可能エネルギの中でも 木質バイオマスは、森林面積が国土の約 67\%とスウェーデ ンとほぼ同じであるにもかかわらず、その利用は十分進ん でいないが、一般家庭における暖房用としてペレットスト ーブに利用され始めている。

本研究では、普及し始めたペレットストーブに着目し、 その排熱により発電を行うペレットストーブ排熱利用発電 システムいわゆる木質バイオマスを利用した小型コージェ ネレーションシステムを構築し、そのシステム性能を実験 的に評価し、その実現の可能性を検証する。

\section{2. 木質バイオマス}

バイオマスには種々あるが、利用しやすいのは木質ペレ ットである。木質ペレットは、製材工場において発生した 端材や森林の間伐材などを粉砕そして高温圧縮成形されて いる。本実験において使用した木質ペレットは図 1 に示す 製材工場で発生した檜の端材を主成分としており、その形 状淔径 $\phi 6.5 \mathrm{~mm}$ 、最大長さ $25 \mathrm{~mm}$ と小さく、粒もそろ い木質バイオマスストーブやボイラにおける燃料の自動 供給に適している。また、その発熱量は $18.5 \mathrm{MJ} / \mathrm{kg} 、 そ し$ て燃焼は安定し、煙をほとんど発生せず、灰分も $0.5 \%$ と
少ない。ところで、国内における木質ペレットの利用はほ とんど普及していない。これは、木質ペレットの供給体制 の不備、さらには使用するストーブやボイラの高価格によ る。ペレットストーブの価格は、国産の普及型ペレットス トーブで 15 万円程度、輸入品で 30〜 40 万程度であり、灯 油ストーブやファンヒータと比べると、高価である。また、 木質ペレットそのものの価格が灯油に比べ割高であったこ とにも起因する。しかし、石油価格の高騰より、灯油価格 が約 2.0 円/MJまで上昇している。木質ペレット価格が 1.5 円/MJ〜3.4 円/MJ であることから、価格面においても競争 力が出てき、灯油や都市ガスを代替する燃料として期待さ れる。

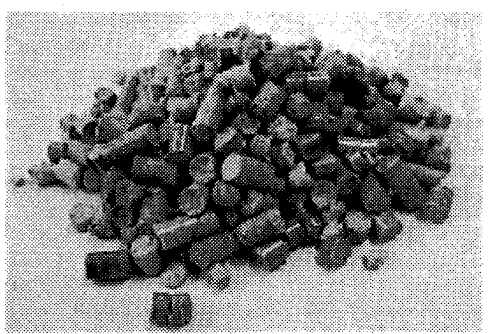

Fig. 1 Wood pellet

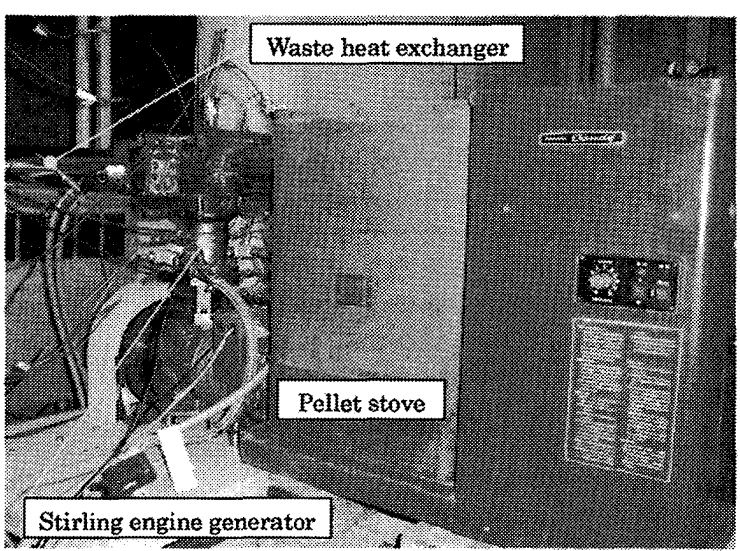

Fig. 2 Co-generation system using wood pellet stove

日本機械学会〔No.06-29]第 10 回スターリングサイクルシンポジウム講演論文集 [2006-10-20,21・横浜 $]$ 


\section{3.ストーブ排熱利用発電システム}

図 2 に本研究にて構築した木質バイオマスストーブを用 いたコージェネレーションシステムを示す。本システムは ペレットストーブ、スターリングエンジン発電機そして排 熱回収熱交換器により構成される。

本システムは、ペレットストーブにて暖房、その排熱に よりスターリングエンジン発電機を用いて発電する。また、 排熱回収熱交換器にて回収した排熱及びスターリングエン ジンにて回収した排熱を給湯に利用することも可能である。 以下に本システムの構成機器とシステム構成を示す。

3.1 ペレットストーブ＼cjkstart使用したペレットストーブ の仕様を表 1 に示す。本ストーブの暖房出力(燃焼熱量)は、

最大約 $24 \mathrm{~kW}$ th 燃料消費量 $1.33 \mathrm{~g} / \mathrm{s}$ )から最小約 $7.9 \mathrm{~kW}$ th $($ 燃 料消費量 $0.43 \mathrm{~g} / \mathrm{s}$ )までの調節が可能であり、木造住宅の場 合、 $32 \mathrm{~m}^{2}$ (室温 $20^{\circ} \mathrm{C}$ )以上の居間の暖房が可能である。とこ ろで、本ストーブの煙突取付口は本来然焼室上部にあるが、 熱回収が容易なように側面に変更している。

図 3 には、ペレットストーブの燃焼熱量とストーブ出口 温度との関係を示す。同図より、最大燃焼熱量 $25 \mathrm{~kW}_{\text {th } ~}$ $21 \mathrm{~kW}_{\text {th }} 、 13 \mathrm{~kW}_{\text {th }} \sim 10 \mathrm{~kW}_{\text {th }}$ そして $8 \mathrm{~kW}_{\text {th }} \sim$ 最小燃焼熱量 の各燃焼範囲においては、各燃焼範囲において排ガス温度 は大きな変化はない。これは、燃料に使用した木質ペレッ 卜の長さが均一でなく、各燃焼熱量において一定量の木質 ペレットが供給されないためと思われる。ところで、燃焼 熱量 $13 \mathrm{~kW}$ th〜最小燃焼熱量の範囲では、排ガス温度が低 く、供しエンジンの自立運転に必要な膨張空間の作動ガス 温度 $350^{\circ} \mathrm{C}$ 以上を得るには不十分であった。したがって、 ストーブの燃焼熱量には、エンジンの自立運転が可能な概 ね $24 \mathrm{~kW}_{\text {th、 }} 21 \mathrm{~kW}_{\text {th }} 15 \mathrm{~kW}_{\text {th }}$ そして $13 \mathrm{~kW}_{\text {th }}$ を選んだ。

Table 1 Specifications of pellet stove

\begin{tabular}{|c||c|}
\hline Combustion method & Forced air blow \\
\hline Combustion load & 8 to $24 \mathrm{~kW}_{\text {th }}$ \\
\hline Fuel & Wood pellet \\
\hline Hopper capacity & $18 \mathrm{~kg}$ \\
\hline Fuel consumption & 1.46 to $4.25 \mathrm{~kg} / \mathrm{h}$ \\
\hline Electric power in operation & 50 to $200 \mathrm{We}$ \\
\hline
\end{tabular}

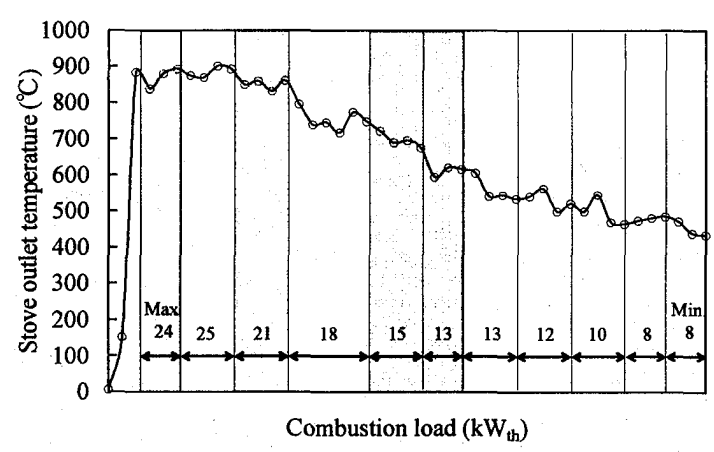

Fig. 3 Relationship between combustion load and outlet temperature of stove

3.2 スターリングエンジン発電機使用したスター リングエンジン発電機の概要を図 4 、その仕様を表 2 に示 す。本エンジンは、マイクロコージェネレーションシステ ム用の試験機である。本エンジンは膨張ピストン、ヒータ、
再生器、クーラ、圧縮ピストンそしてクランク軸に接続し た発電機により構成される。本エンジンの最高発電出力は $0.5 \mathrm{kWe}$ 程度であるが、エンジン性能はストーブの排気ガ ス温度や排熱量に依存するので、これだけの出力は期待で きない。実験に際しては、ヒータ外壁温度そして膨張空間 及び圧縮空間の作動ガス温度はシースタイプの $\mathrm{K}$ 型並び に T 型熱電対にて測定する。また、膨張空間及び圧縮空間 の圧力はひずみ線式エンジン指圧計により測定し、動ひず み測定器そして A/D ボードを介して PC 上の波形収集シス テムにてデータ処理を行う。冷却水の流量はマスフローメ 一タにて測定し、その出入口温度差はサーミスタセンサに て測定する。また、発電機により得られた電力は電力計に 表示する。

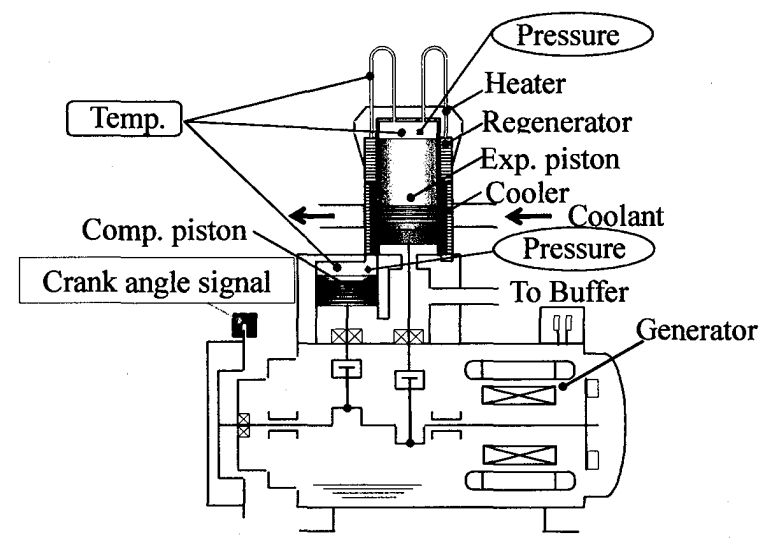

Fig. 4 Schematic of Stirling engine generator

Table 2 Specifications of Stirling engine generator

\begin{tabular}{|c||c|}
\hline $\begin{array}{l}\text { Stroke volume in exp. } \\
\text { and comp. space }\end{array}$ & $99 \mathrm{~cm}^{3}$ \\
\hline Initial sealed gas & He $(2 \mathrm{MPa})$ \\
\hline Heater & Tubular type \\
\hline Cooler & Plate fin \\
\hline Regenerator & Stacked wire gauze \\
\hline Engine type & $\alpha$ type \\
\hline Cooling method & Tap water $(8.0 \mathrm{~L} / \mathrm{min})$ \\
\hline Generator & Synchronous type \\
\hline Size & W700 $\times$ D800 $\times$ H900 \\
\hline
\end{tabular}

3.3 システム構成 図 5 にバイオマスストーブ排熱 利用スターリングエンジン発電システムの概要に示す。ペ レットストーブの排気出ロに設けた煙突にはスターリング エンジンのヒータ部分そしてその後ろには排熱回収熱交換 器が設置されている。排ガス温度の測定には、シースタイ プ K 型熱電対を用いる。排ガス温度は、ストーブと煙突の 接続部分であるストーブ出口を $0 \mathrm{~mm}$ として、ヒータ入口 $265.5 \mathrm{~mm}$ 、ヒータ左右 $317 \mathrm{~mm}$ 、ヒータ出口 $368.5 \mathrm{~mm}$ 、 排熱回収熱交換器入口 $577 \mathrm{~mm}$ 、排熱回収熱交換器出口 $1367 \mathrm{~mm}$ そして煙突出口 $2233 \mathrm{~mm}$ の各部にて測定する。 排熱回収熱交換器の熱回収媒体には水道水を用いる。熱媒 体の出入口温度は、サーミスタセンサにより測定する。

システム評価は、図 5 中の排熱回収熱交換器の有無の影 響についても実施する。実験に際して、充填圧力 $2.0 \mathrm{MPa}$ のヘリウムを本エンジンに封入後、所要の然焼負荷になる ようストーブの燃焼目盛を調節する。その後、排気ガス温 度、熱媒体流量そしてエンジン内の作動空間温度の安定性 を確認後、各部の温度、クーラにおける冷却水流量そして 


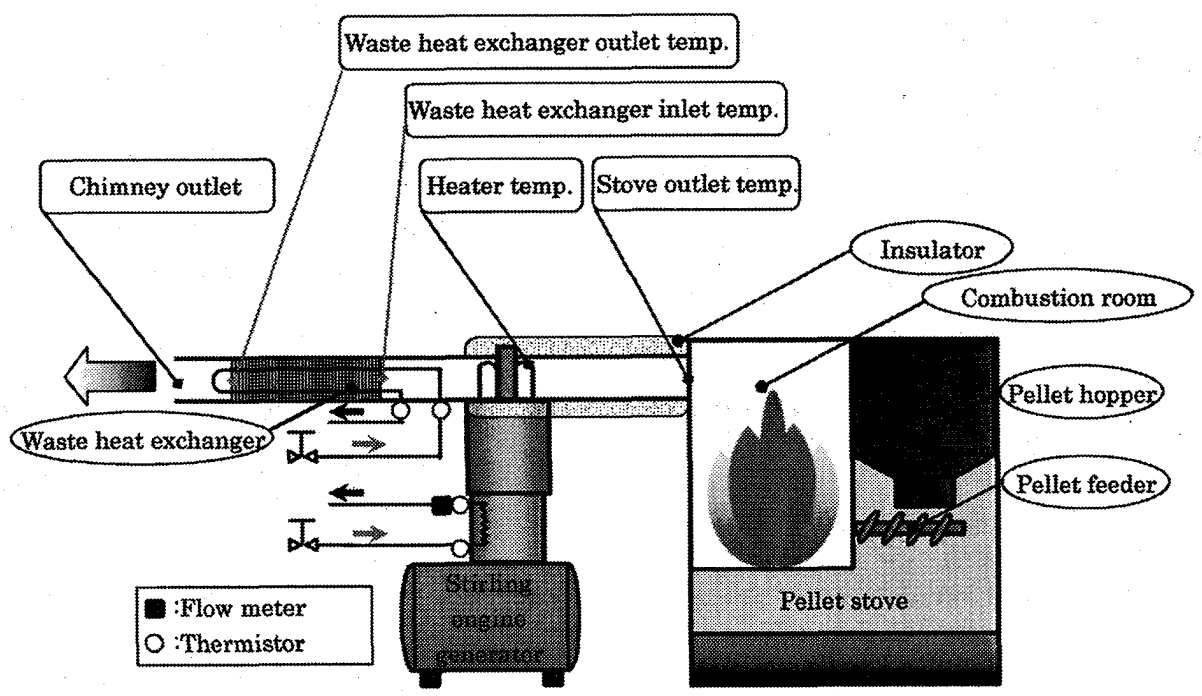

Fig. 5 Schematic of co-generation system using a pellet stove

作動ガス圧力を測定する。

\section{4. システム性能評価}

図 6 に排熱利用が発電のみの排熱回収熱交換器を有しな い場合について、最大燃焼負荷時のエンジン性能を示す。同 図によると、エンジン熱回収量は回転数の増加に伴い増加し、 回転数 $800 \mathrm{rpm}$ において $1.3 \mathrm{~kW}$ th そして回転数 $1100 \mathrm{rpm}$ に おいて $1.6 \mathrm{~kW}_{\text {th }}$ 得られる。図示出力は回転数 $900 \mathrm{rpm}$ におい て最大 $494 \mathrm{~W} 、 そ の$ 際の発電出力 $174 \mathrm{We}$ が得られた。

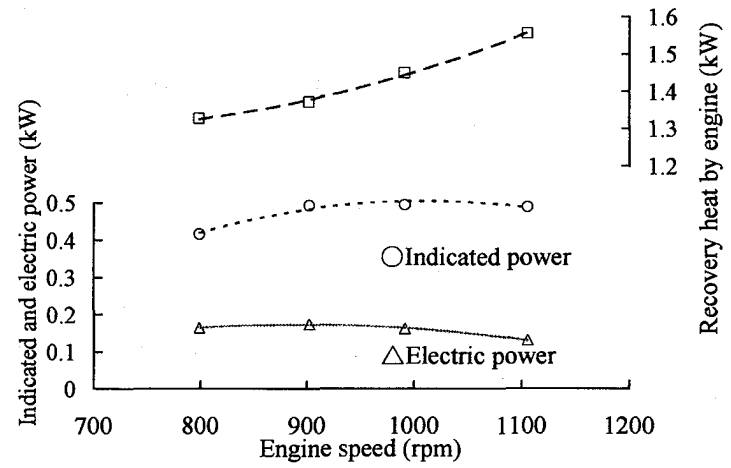

Fig. 6 Engine performance in system without waste heat exchanger at large combustion load

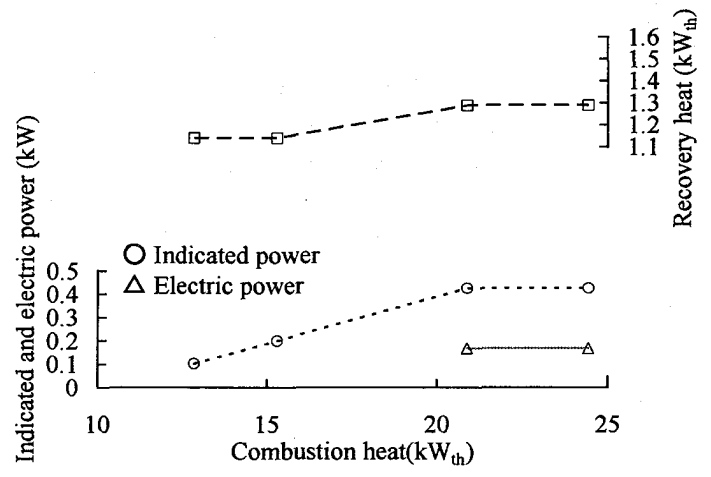

Fig. 7 Characteristics in system without waste heat exchanger
図 7 には、排熱利用が発電のみの場合について、エンジン 回転数 800rpm におけるシステム性能を示す。同図によると、 エンジンの泠却水による熱回収量は $1.1 \mathrm{~kW}_{\text {th }}$ から $1.3 \mathrm{~kW}$ th である。図示出力は $102 \mathrm{~W}$ から $425 \mathrm{~W}$ 得られ、電力は最大 燃焼熱負荷時において $169 \mathrm{We}$ 得られる。しかし、電力は最 大燃焼負荷時においてのみ得られた。これは、図 8 に示す燃 焼熱量に対するヒータ温度及び膨張室温度から分かる。ヒー 夕温度は、燃焼熱量 $13 \mathrm{~kW}$ th から $15 \mathrm{~kW}_{\text {th }}$ において $440^{\circ} \mathrm{C}$ か

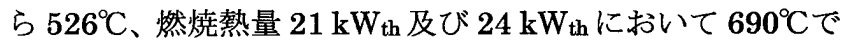
ある。膨張室温度は、燃燒熱量 $13 \mathrm{~kW}$ th て $233^{\circ} \mathrm{C}$ から $289^{\circ} \mathrm{C}$ 、燃焼熱量 $21 \mathrm{~kW}_{\text {th }}$ 及び $24 \mathrm{~kW}$ th におい

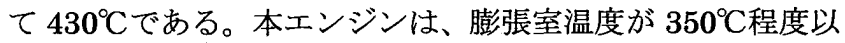
上に達しないと電力が得られないことから、本システムに合 ったエンジン開発も必要になる。

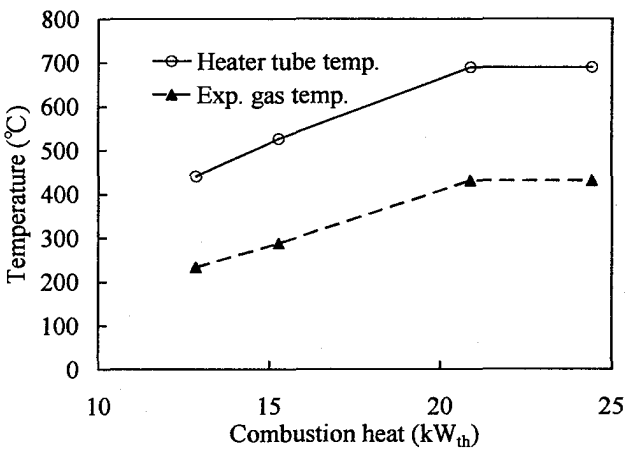

Fig. 8 Temperature of heater tube and expansion space

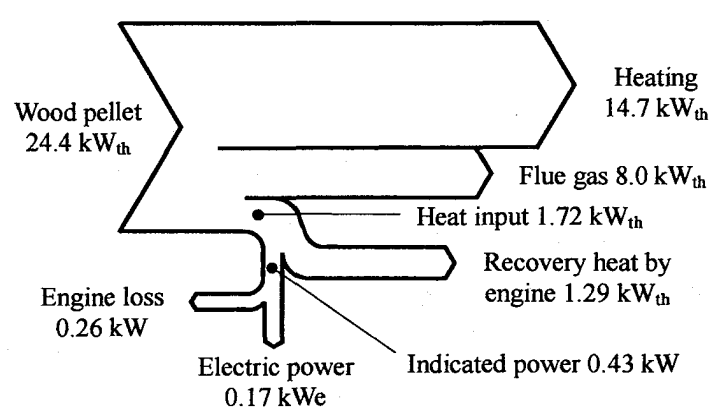

Fig. 9 Energy flow in system without waste heat exchanger 
図 9 には、排熱利用が発電のみの場合について最大の電力 が得られた最大燃焼負荷時におけるエネルギフローを示す。 同図より、木質ペレットの燃焼熱量 $24.4 \mathrm{~kW}$ th に対して、暖 房出力 $22.7 \mathrm{~W}_{\mathrm{th}}$ (大気への放熱量も含む)、エンジンクーラ部 にて回収した熱量 $1.29 \mathrm{~kW}_{\mathrm{th}}$ そして電力 $169 \mathrm{~W}_{\mathrm{e}}$ を得られた ことが分かる。

図 10 には、排熱利用が発電と排熱回収の場合におけるシ ステム性能を示す。同図によると、排熱回収量は $1.9 \mathrm{~kW}$ th から $3.0 \mathrm{~kW}$ th 得られる。エンジン熱回収量は $1.1 \mathrm{~kW}$ th から $1.4 \mathrm{~kW}_{\mathrm{th}}$ である。本システムから回収できる熱量は排熱回収 量とエンジン熱回収量を合わせて $3.0 \mathrm{~kW}$ th から $4.4 \mathrm{~kW}$ th 得 られる。図示出力は $65 \mathrm{~W}$ から $404 \mathrm{~W}$ 、そして電力は最大然 焼負荷時において $158 \mathrm{We}$ 得られている。

図 11 には、排熱利用が発電と排熱回収の場合におけるエ ネルギフローを示す。同図より、木質ペレットの燃焼熱量 $24.4 \mathrm{~kW}_{\text {th }}$ に対して、暖房出力 $19.6 \mathrm{~kW}$ th (大気への放熱量も 含む)、排熱回収熱交換器にて回収した熱量 $3.05 \mathrm{~kW}$ th、エン ジンクーラ部にて回収した熱量 $1.29 \mathrm{~kW}$ th、すなわち、本シ ステムにて回収した総熱量 $4.34 \mathrm{~kW}_{\text {th }}$ そして電力 $158 \mathrm{~W}_{\mathrm{e}}$ を 得られたことが分かる。本システムにおける排熱回収熱交換 器の有無の影響は電力の発生に現れ、熱交換器の無いシステ ムにおいて得られる電力の方が高い。この原因として、排熱 回収熱交換器における流動抵抗が考えられる。実際、排熱回 収熱交換器を有するシステムにおける実験中の煙突から黒 煙の排出が確認されている。これは、排熱回収熱交換器内部 に設置されたフィンが排ガスに対し流動抵抗を与えるため 木質ペレットが不完全燃焼を起こしたことが考えられる。 すなわち、排熱回収熱交換器を設けたシステムの場合には、 その流動抵抗により発生電力を低下させる一因になる。また、 ストーブの燃焼室内に蓄積した灰による木質ペレットの不 完全燃焼も考えられる。図 12 には、実験後の燃焼室内部に 蓄積した灰を示す。図 12(a)は木質ペレットの完全燃焼によ り生成した灰であり、燃焼室内の灰受けに存在する。図 $12(\mathrm{~b})$ は不完全燃焼により生成した灰であり、燃焼室内の吸気口付 近に存在する。これは、長時間ストーブを運転することによ り蓄積した灰が吸気口を塞ぎ木質ペレットが不完全燃焼を

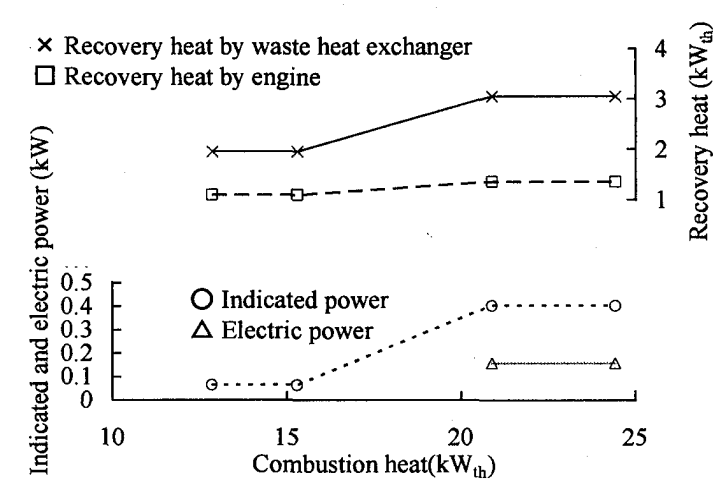

Fig. 10 Characteristics in system with waste heat exchanger

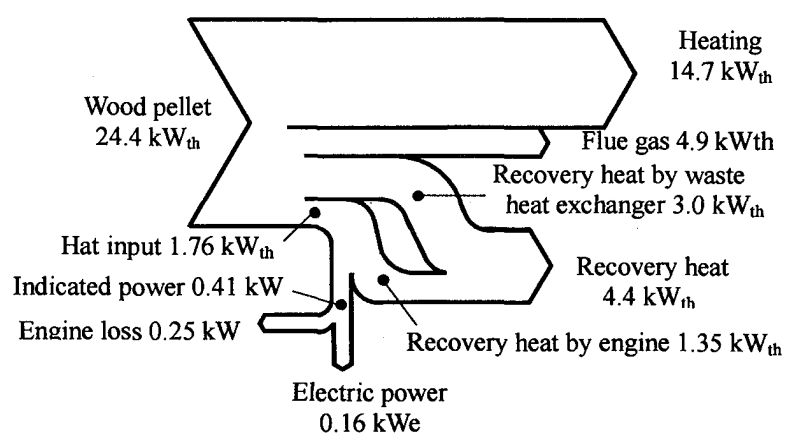

Fig. 11 Energy flow in system with waste heat exchanger
起こしたと考えられる。ところで、木質ペレットの灰分がス ターリングエンジンのヒータ部に付着し、伝熱性能を低下さ せることによりエンジン性能が低下させることが考えられ る。そこで、燃焼前後のヒータチューブの様子を図 13 に示 す。同図によると、それほどの灰分の付着が見られず、エン ジンが然焼室から離れた排気管に設置されているため、灰分 のエンジン性能への影響は少ないものと思われる。

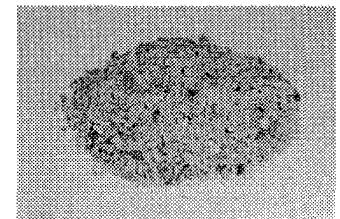

(a) Complete combustion

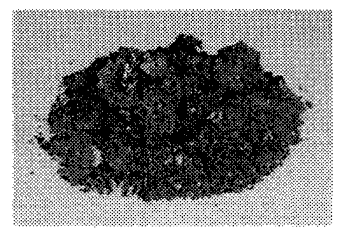

(b) Incomplete combustion

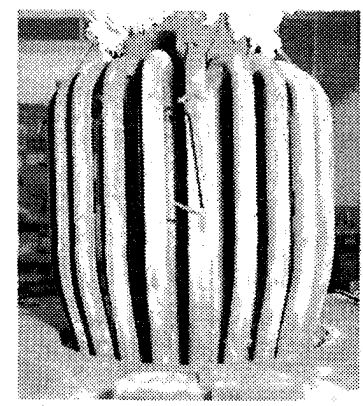

(a) Before experiment

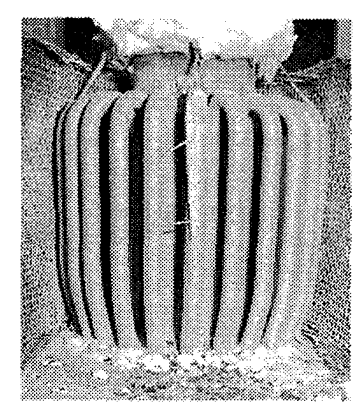

(b) After experiment
Fig. 13 Ash on heater tube

\section{5. 結 言}

スターリングエンジン発電機を用いた木質ペレットスト 一ブ排熱利用発電システムを構築し、その性能評価を実験的 に行った結果、次の成果が得られた。

(1)本システムの場合、ストーブの燃焼熱量が $20 \mathrm{~kW}$ th 以上の 最大燃焼時においてのみ、排熱温度が $700^{\circ} \mathrm{Cを}$ を越え、供し スターリングエンジンの駆動が可能となった。

(2)排熱利用が発電のみの場合、燃燒熱量 $24 \mathrm{~kW}$ th に対して電 力 $194 \mathrm{~kW}$ 薄得られた。

(3)排熱利用が発電と排熱回収の場合、燃焼熱量 $24.4 \mathrm{~kW}$ th 対して電力 $160 \mathrm{~W}_{\mathrm{e}}$ と熱回収量 $4.4 \mathrm{~kW}$ th

本実験により、木質ペレットストーブの排熱を利用した発 電、すなわち熱需要を主としたバイオマスマイクロコージェ ネレーションシステムの可能性が検証できた。

\section{文 献}

(1)有限会社東京木質資源活用センター、「木質ペレット然料 の仕様」http://www.tokyopellet.jp/

(2)農林水産省、「バイオマス・ニッポン総合戦略パンフレッ 卜」http://www.maff.go.jp/biomass/index.htm

（3）大場龍夫、「森林改良普及双書 No.149 森林バイオマス最 前線」、(社)全国林業改良普及協会 (2005)、p30-37.

(4)小澤祥司、「木質ペレットとペレットストーブの基礎」、 ソーラーシステム、No.102、(株)ソーラーシステム研究 所、 p22-29. 